\title{
TREATMENT OF POME BY PILOT PLANT ANAEROBIC FLUIDISED BED REACTOR
}

\author{
A. A. MAMUN ${ }^{1 *}$ AND A. IDRIS ${ }^{2}$ \\ ${ }^{I}$ Department of Biotechnology Engineering, Faculty of Engineering, International Islamic \\ University Malaysia, Jalan Gombak, 53100 Kuala Lumpur, Malaysia. \\ e-mail:mamun@iiu.edu.my Fax: +603-61964442 \\ ${ }^{2}$ Department of Chemical \& Environmental Engineering, Faculty of Engineering, Universiti \\ Putra Malaysia, 43400 UPM Serdang, Selangor, Malaysia. \\ email:azni@eng.upm.edu.my Fax:+603-86567120
}

\begin{abstract}
A pilot scale anaerobic fluidised bed reactor (AnFBR) of $2000 \mathrm{~L}$ capacity was studied to determine its ability to treat palm oil mill effluent (POME). The pilot plant was operated at ambient temperature with diluted POME as substrate. It took 17 days for the start-up of the reactor with pre-seeded sand media. The mean influent concentration of BOD, COD and TSS were 1110, 2194 and 1004, respectively. The AnFBR was capable to remove a large portion of organics at relatively shorter retention time. Maximum and minimum COD removal efficiency of $85 \%$ and $65 \%$ were attained at a loading rate of 4.0 and $13.8 \mathrm{kgCOD} / \mathrm{m}^{3} . \mathrm{d}$. BOD and TSS removal rates varied within the range of $64 \%-91 \%$ and $68 \%-89 \%$, respectively. The average residual COD, BOD and TSS concentration was 330, 95 and $110 \mathrm{mg} / \mathrm{L}$, respectively. The AnFBR exhibited less sludge production with lower values of sludge volume indices (SVI). Maximum and minimum effluent indices for the effluent were $35 \mathrm{~mL} / \mathrm{g}$ and $11 \mathrm{~mL} / \mathrm{g}$, respectively. Low SVI values indicated that, anaerobic fluidised bed reactors generate less sludge with fast settling properties. Promising performance at ambient temperature and for detention time shorter than the present practices supported the possibility of AnFBR to pretreat POME to meet the new requirement set by the DOE Malaysia.
\end{abstract}

Keywords: Anaerobic Digestion, Palm Oil Mill Effluent, Pilot Scale Bioreactor.

\section{INTRODUCTION}

Palm oil mill effluent (POME) is the single largest source of industrial wastewater pollution in Malaysia. The commonly used conventional treatment facilities (e.g. holding ponds, decanter, anaerobic digesters and aerated lagoons) are unable to meet the guidelines [1] set by the Department of Environment (DOE), which sets BOD as a controlling parameter with a limit of $100 \mathrm{mg} / \mathrm{L}$. Therefore, high rate treatment systems are necessary to treat POME to protect the river system from water pollution.

Anaerobic treatment of industrial wastewaters is a well-established technology, which has been proven to be the cheapest and versatile method for a wide range of application [2]. New process innovations like high-rate filtration, fluidised bed [3] up-flow sludge blanket [4] and hybrid reactors [5] have already emerged as today's most viable anaerobic treatment technology. Among them anaerobic fluidised bed reactor (AnFBR) has been used for wastewater treatment since early 1970s. Promising features of the AnFBRs are the capability of treating high strength wastewaters at both ambient and elevated temperatures [6] for a 
minimum energy, with low sludge production and ability to tolerate shock loads in terms of volumetric loading rates (VLRs), $\mathrm{pH}$ and temperature without any substantial long term detrimental effects. As such, AnFBR could be a potential system to treat POME to meet the target set by the DOE. Therefore, the overall performance of a pilot plant anaerobic fluidised bed reactor in treating palm oil mill effluent (POME) is reported in this paper.

\section{MATERIALS AND METHODS}

\subsection{Substrate Characteristics}

Various types of solids, semisolids and liquid wastes are generated from different steps of oil processing units of an oil palm industry. In practice, all these wastes are bulked which gives a yellowish liquor containing both dissolved and fine suspended matter and residual oil with very high BOD and COD values. The slightly acidic wastewater consists of about $90-95 \%$ water, $5-10 \%$ total solids and $0.5-1 \%$ residual oil and grease [7]. In this study, the POME was diluted 10 times with distilled water to overcome the problem of collecting huge amount of wastewater required to run the system. General characteristics of undiluted raw POME and diluted substrate for the pilot plant are given in Table 1.

Table 1: Typical Characteristics of the Substrate (POME)

\begin{tabular}{lcccc}
\hline Parameter & Ma [7] & Kam [8] & $\begin{array}{c}\text { This Study } \\
\text { (Undiluted POME) }\end{array}$ & $\begin{array}{c}\text { Diluted } \\
\text { Substrate }\end{array}$ \\
\hline BOD (mg/L) & 25,000 & 34,000 & 31,240 & $990-2080$ \\
COD (mg/L) & 50,000 & 62,000 & 59,700 & $2,000-5,000$ \\
TSS (mg/L) & 18,000 & 37,000 & 30,230 & $959-1,937$ \\
VSS (mg/L) & 34,000 & 26,000 & 25,300 & $735-1,596$ \\
O\&G (mg/L) & 6,000 & - & 8,000 & - \\
TN (mg/L) & 750 & - & 1,940 & - \\
TP (mg/L) & - & - & 268 & - \\
pH (-) & 4.2 & 4.3 & 4.5 & 7.0 \\
\hline
\end{tabular}

\subsection{Reactor Properties}

The reactor was fabricated based on the geometrical up-scaling of the lab-scale reactors studied by Hafiz [9] and Tiong [10]. Mild steel plates, available in the market, was used to build the $3.8 \mathrm{~m}$ tall reactor. Top portion of the reactor was tapered to increase the diameter and to reduce the upward velocity in order to minimise the unwanted wash out of any biosolids.

\subsubsection{Dimensions of the AnFBR}

According to the actual scale-up ratio, required volume of the reactor was $5000 \mathrm{~L}$. However, due to various limitations, diameter of the AnFBR was limited to $770 \mathrm{~mm}$, which resulted in a total reactor volume of about $2000 \mathrm{~L}$ and an aspect ratio (H/D) of 4.94. High aspect ratio was preferred for better mixing and easy fluidisation but not critical for system performance [11]. Technical and logistic support was not available to build and install a taller reactor keeping the volume and aspect ratio high. Schematic diagram of the reactor is shown in Fig. 1. 


\subsubsection{Media Properties}

Natural sands were chosen to be used as media for the reactor due its easy availability, low cost and high stability. Random grab samples were taken from the dried sands and analysed to determine particle size distribution. One third of the media had a particle diameter of $0.35 \mathrm{~mm}$ to $0.56 \mathrm{~mm}$ and only $10 \%$ of the materials had a diameter of less than $0.20 \mathrm{~mm}$. Uniformity coefficient $\left(\mathrm{C}_{\mathrm{u}}\right)$ and coefficient of gradation $\left(\mathrm{C}_{\mathrm{c}}\right)$ of the media was 1.60 and 1.09 respectively. These media provided an approximate specific surface area of $5237 \mathrm{~m}^{2} / \mathrm{m}^{3}$ of media volume.

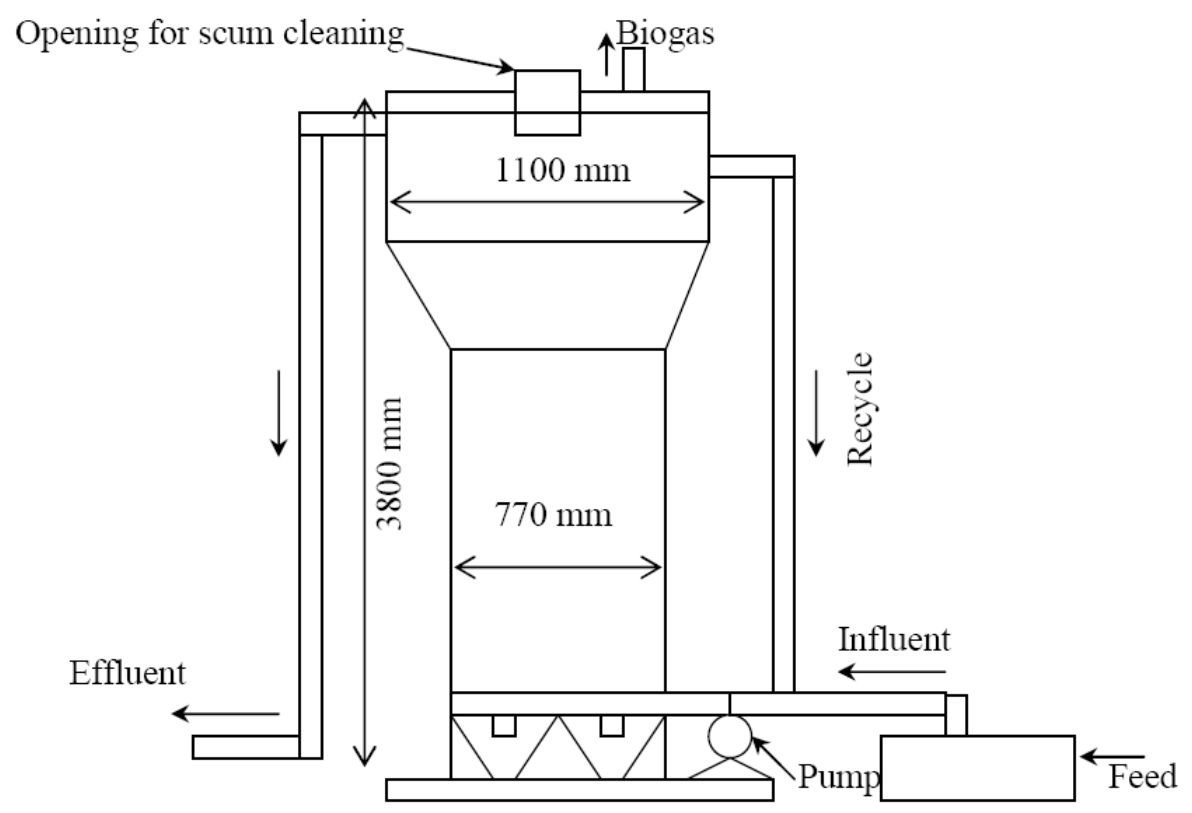

Fig. 1: Schematic Diagram of the AnFBR Pilot Plant (not to scale).

\section{RESULTS AND DISCUSSION}

A few technical problems, such as leaking through improperly welded joints, pump malfunction and breakdown of the piping system delayed the full operation of the pilot plant anaerobic fluidised bed reactor.

\subsection{Start-up of the Reactor}

In order to overcome the start-up problem experienced by Hsu and Shieh [12], the sand media were pre-seeded in a tank for three months. The media were fed with raw POME and stirred (manually) twice a day. During the start-up period, the volumetric loading rate was between 1.8 and $2.0 \mathrm{kgCOD} / \mathrm{m}^{3}$.d at an HRT of 24 hours. About $200 \mathrm{~L}$ of active sludge from an anaerobic pond was mixed with the feed. COD removal rate was considered as the controlling parameter to study the start-up performance. However, BOD, COD, TSS and SVI were monitored after the start-up of the reactor. Due to presence of solids and biomass in the pre-seeded media, effluent COD on the first day was higher than that of the influent (Fig. 2). 


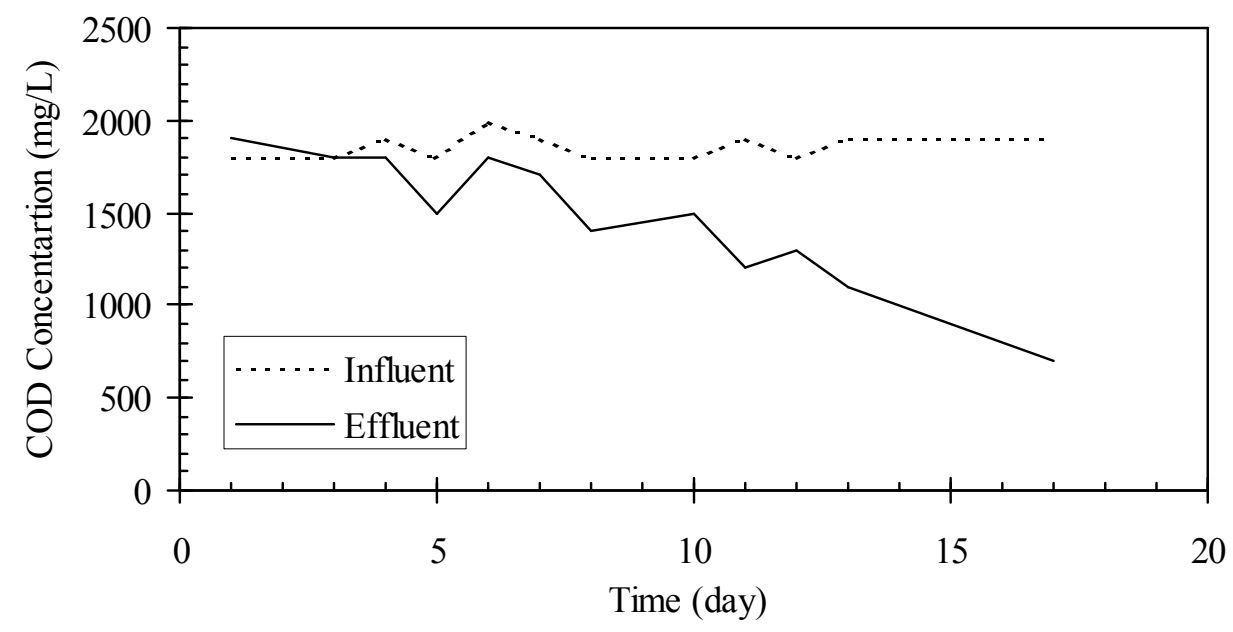

Fig. 2: Influent and Effluent COD during the Start-up of the Reactor

With average chemical oxygen demand (COD) concentration of $2100 \mathrm{mg} / \mathrm{L}$, Oliva et al. [13] obtained a start-up within 14 days for a full-scale brewery wastewater treatment plant. Tiong [10] completed start-up period when the COD removal rate was around $86 \%$ and Hafiz [9] ended start-up when COD removal efficiency varied between $70 \%$ and $80 \%$. Thus, the start-up in this study was completed when the COD removal rate was around $70 \%$. From Fig. 2 it was observed that, the reactor could start at an early period of 17 days, indicating that pre-seeding of media might be an alternative way to get an early start-up of fixed film reactors. On the other hand, Denac and Dunn [14] obtained start-up of the reactor within 21 days.

\subsection{Pollutant Removal}

Many forms of substrates, including BOD, COD and solids were monitored to study the performance of the AnFBR for POME treatment. The influence of the applied substrate on the reactor performance is discussed according to the forms of substrates. Five steady state conditions were attained and, for the simplicity of the discussion, were termed as Run 1, 2, 3, 4 and Run 5. Values of different parameters at each steady state are given in Table 2. Influent concentration was doubled for Run 4 and 5.

\subsubsection{BOD Removal}

Biochemical oxygen demand (BOD) was determined every week and at the steady states. The observation of BOD removal rate against operation time revealed that removal rate increased at a higher rate during the 1st run at HRT of $12 \mathrm{hrs}$ and the maximum removal rate was observed to be $91.4 \%$ at the loading rate of $2.6 \mathrm{kgBOD} / \mathrm{m}^{3} . \mathrm{d}$ (Table 2). Minimum BOD removal rate throughout the whole operation was $64.7 \%$ at 4 -hour retention time with a VLR of $6.1 \mathrm{kgBOD} / \mathrm{m}^{3} . \mathrm{d}$. From the plot of specific Biological Loading Rate (BLR) applied and utilised as $\mathrm{kgBOD} / \mathrm{kgVSS}$.d (Fig. 3), it can be noticed that specific substrate utilization rates decreased with the increase in loading rate. Fig. 4 indicated that BOD removal rate decreased from $91.4 \%$ to $64.7 \%$ with the increase in Volumetric Loading Rate (VLR) from $1.5 \mathrm{kgBOD} / \mathrm{m}^{3} . \mathrm{d}$ to $6.12 \mathrm{kgBOD} / \mathrm{m}^{3} . \mathrm{d}$. 
Table 2: AnFBR Performance at Different Steady State Conditions

\begin{tabular}{lccccc}
\hline Parameter & Run 1 & Run 2 & Run 3 & Run 4 & Run 5 \\
\hline HRT (hr) & 12 & 8 & 4 & 24 & 12 \\
Influent BOD (mg/L) & 1280 & 1030 & 1020 & 1640 & 1800 \\
Effluent BOD (mg/L) & 110 & 260 & 360 & 300 & 570 \\
BOD Load (kg/m $\left.{ }^{3} . \mathrm{d}\right)$ & 2.6 & 3.1 & 6.1 & 1.6 & 3.6 \\
BOD Removal (\%) & 91.4 & 74.8 & 64.7 & 81.7 & 68.3 \\
Influent COD (mg/L) & 2000 & 2200 & 2300 & 4600 & 5000 \\
Effluent COD (mg/L) & 300 & 500 & 800 & 1000 & 1800 \\
COD Load (kg/m $/ . \mathrm{d})$ & 4.0 & 6.6 & 13.80 & 4.6 & 10 \\
COD Removal $(\%)$ & 85.0 & 77.3 & 65.22 & 78.3 & 70 \\
Influent TSS (mg/L) & 959 & 967 & 1081 & 1772 & 1937 \\
Effluent TSS (mg/L) & 105 & 230 & 302 & 483 & 619 \\
TSS Load $\left(\mathrm{kg} / \mathrm{m}^{3} . \mathrm{d}\right)$ & 1.9 & 2.9 & 6.49 & 1.8 & 3.9 \\
TSS Removal $(\%)$ & 89.1 & 76.2 & 72.10 & 72.7 & 68 \\
\hline
\end{tabular}

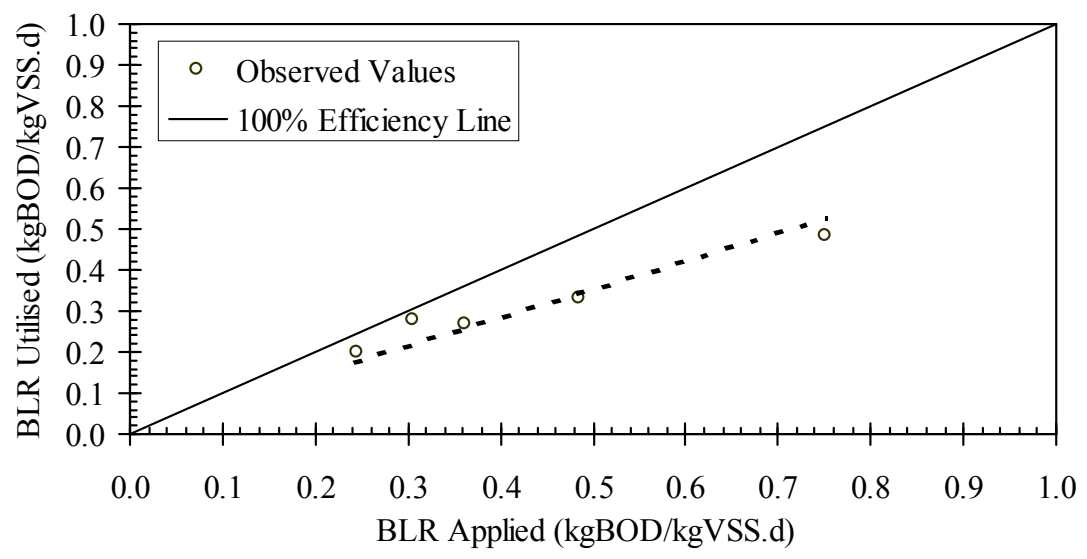

Fig. 3: Specific BOD Removal Rate as Biological Loading Rate (BLR)

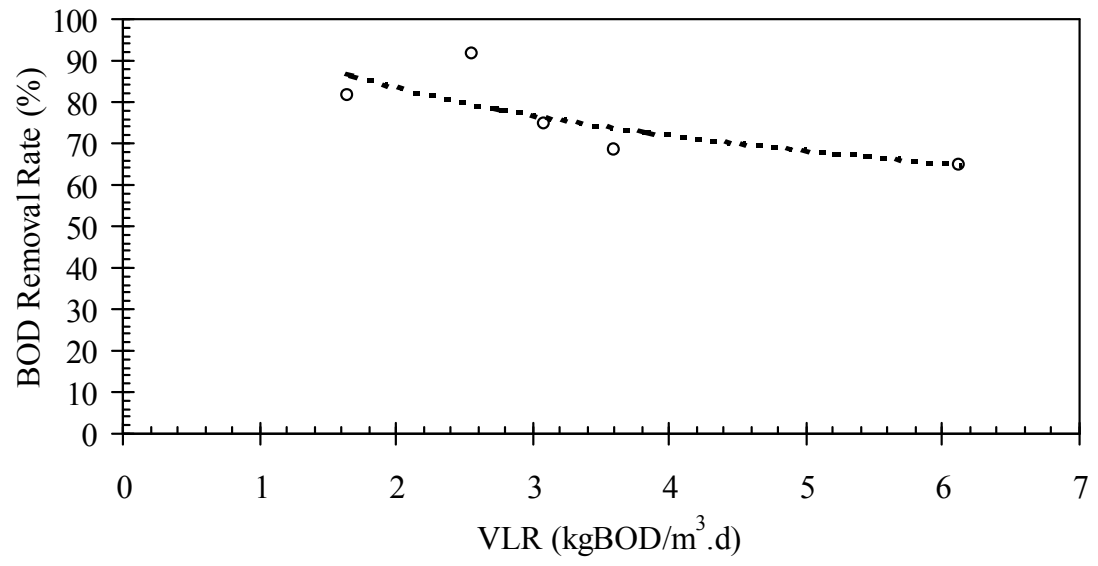

Fig. 4: Variation of BOD Removal Rate with Volumetric Loading Rate (VLR) 


\subsubsection{COD Removal}

Effluent COD concentration increased with the increased loading rate. Effluent COD concentration was the highest at $1800 \mathrm{mg} / \mathrm{L}$ in the 5 th run when the influent COD was $5000 \mathrm{mg} / \mathrm{L}$. Influent COD was doubled in the 4th and 5th run and subsequent fluctuations were observed for the effluent COD. The Maximum COD removal rate achieved at steady state was $85 \%$ and the minimum was $65.2 \%$ (Table 2). This was achieved at HRT of 12 and 4 hour under VLR of 4.0 and $13.8 \mathrm{kgCOD} / \mathrm{m}^{3} . \mathrm{d}$, respectively. It was observed that the COD removal rate decreased steadily with increasing loading rate (Fig. 5). This observation was in agreement with the trend reported by Chen et al. [15]. A similar trend is noticed in Fig. 5. However, even during the stabilisation periods during each run, the removal rate of COD never dropped below $45 \%$.

At steady states, most of the removal rates were within 5\% variation. This indicates that, the AnFBR was able to absorb minor changes in influent concentration. The maximum specific COD utilization at steady states was $1.4 \mathrm{kgCOD} / \mathrm{kgVSS}$.d when the applied load was $1.76 \mathrm{kgCOD} / \mathrm{kgVSS}$.d (Fig. 6).

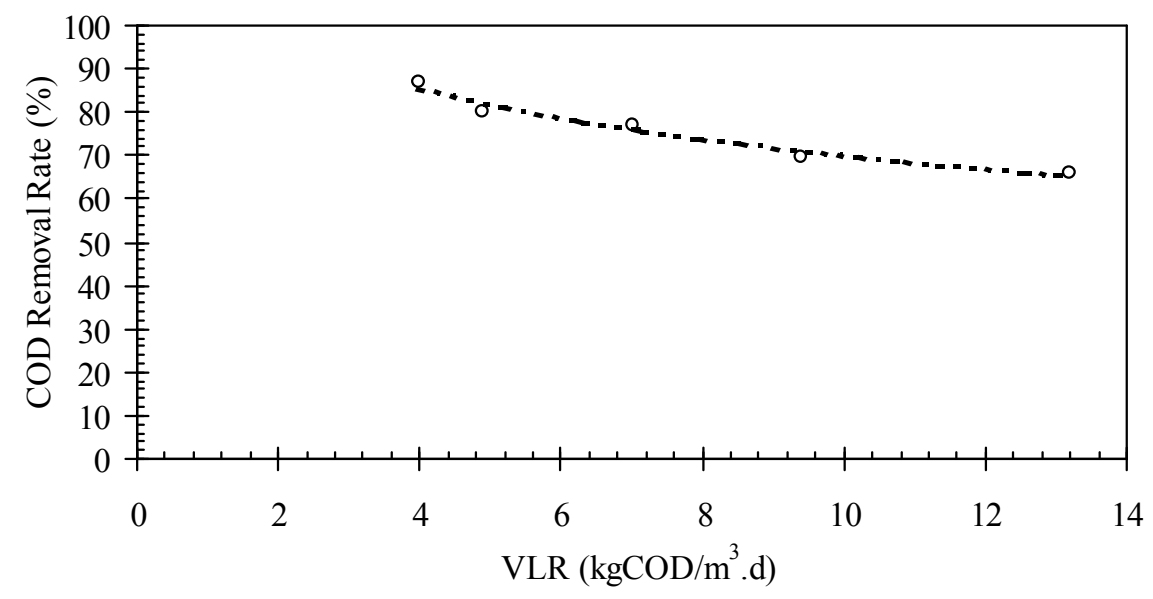

Fig. 5: Variation of COD Removal Rate with Volumetric Loading Rate (VLR)

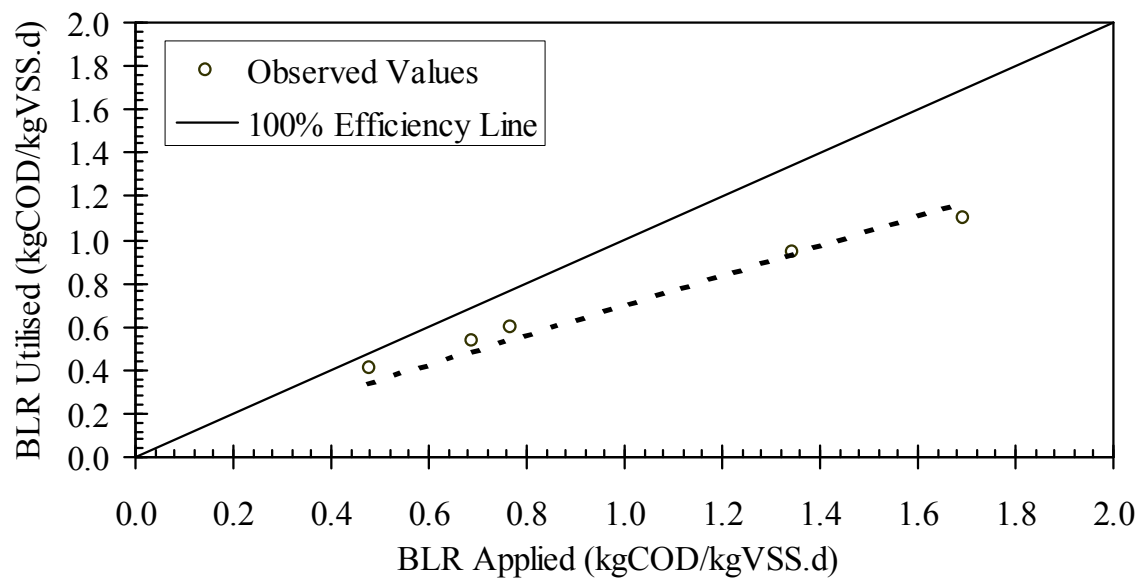

Fig. 6: Specific COD Removal Rate as Biological Loading Rate (BLR) 


\subsubsection{TSS Removal}

TSS removal rate throughout the 1st run was excellent. Maximum TSS removal rate achieved was $89 \%$ at an HRT of 12 hour. This removal rate was achieved at a VLR of $1.92 \mathrm{kgTSS} / \mathrm{m}^{3}$.d (Table 2). Specific TSS utilization rate was analysed in a fashion similar to those of BOD and COD analysis. As expected, the specific TSS removal rate deviated from the $100 \%$ efficiency line with the increase in loading rates. TSS removal efficiency was declining with the increase in VLR but the decrement was less at loading rates greater than $4 \mathrm{kgTSS} / \mathrm{m}^{3}$.d.

\subsubsection{Sludge Volume Index}

Sludge Volume Index (SVI) was measured in all steady states using a conical flux of $1 \mathrm{~L}$ volume (Fig. 7) and using the following relationship:

$$
\mathrm{SVI}=(\text { Settled sludge volume in } \mathrm{mL} \text { in } 30 \text { minutes }) \times 1000 /(1 \mathrm{~L} \times \mathrm{TSS} \text { in } \mathrm{mg} / \mathrm{L})
$$

Lower values of SVI indicate good settle ability of sludge and vice versa. It was observed that SVI improved when there were sufficient solids in the sample. There could be some relation between SVI and minimum sludge concentration [16], which affects the floc formation, sludge compaction and SVI values as well. Maximum and minimum effluent sludge volume indices were $35 \mathrm{~mL} / \mathrm{g}$ and $11 \mathrm{~mL} / \mathrm{g}$ respectively. SVI values less than 100 proved that, similar to other anaerobic processes, AnFBR also produces less sludge which is good for efficient wastewater management.

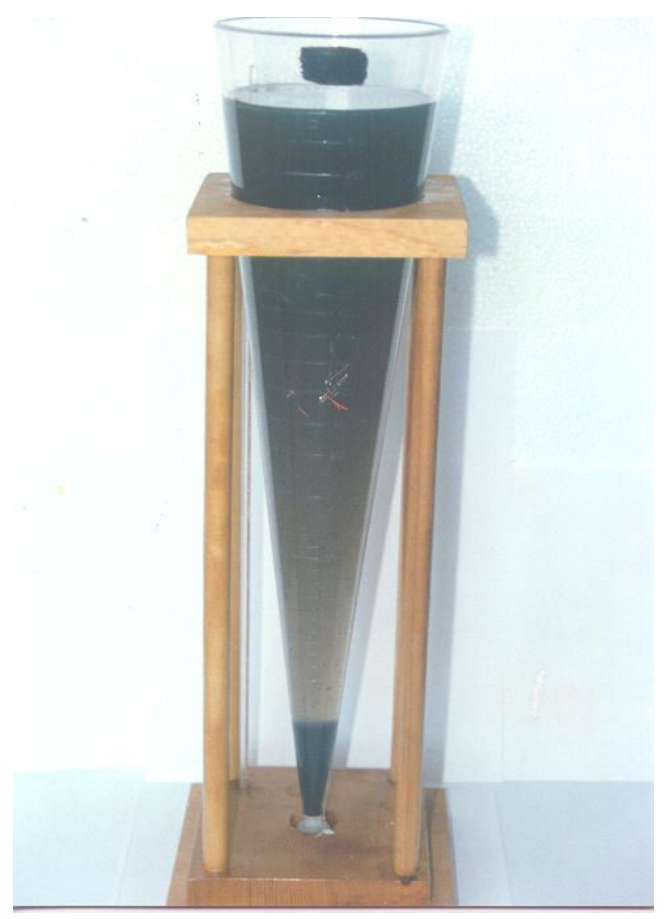

Fig. 7: Sludge Volume Index (SVI) Test. 


\section{CONCLUSIONS}

An early start-up period of 17 days was experienced with pre-seeded media for the pilot plant anaerobic fluidised bed reactor to treat POME. The AnFBR was capable of removing a large portion of organics at relatively shorter HDT from 4 to $24 \mathrm{hr}$ indicating that successful operation of AnFBR is possible at ambient temperature of Malaysian climate. Maximum COD removal efficiency of $85 \%$ was attained at an HRT of $12 \mathrm{hr}$ with a loading rate of $4.0 \mathrm{kgCOD} / \mathrm{m}^{3}$.d. The minimum COD removal rate was $65 \%$ at a VLR and HDT of $13.8 \mathrm{kgCOD} / \mathrm{m}^{3} . \mathrm{d}$ and $4 \mathrm{hr}$ respectively. BOD and TSS removal rates varied within the range of $64 \%-91 \%$ and $68 \%-89 \%$ respectively. Influent concentration had marked effect on removal efficiency. Reactor performance was found to decrease steadily with the increase in loading rate. During the whole operation, the AnFBR exhibited low sludge production with lower sludge volume indices (SVI). Maximum and minimum effluent indices for the effluent were $35 \mathrm{~mL} / \mathrm{g}$ and $11 \mathrm{~mL} / \mathrm{g}$, respectively. Low SVI values indicated that, anaerobic fluidised bed reactors generate less sludge with fast settling properties. Promising performance at ambient temperature and hydraulic retention time shorter than the present practices supported the feasibility of AnFBR for full-scale installation in the palm oil producing industries. However, additional polishing would be necessary through aerobic system and settling tank (clarifier) to further reduce the COD, TSS and other pollutants in the effluent produced by the anaerobic digester.

Acknowledgement: This study was financed by Ministry of Science, Technology and Environment Malaysia; IRPA grant No 50384: High-Rate Waste Treatment.

\section{REFERENCES}

[1] DOE. "Environmental quality act." Department of Environment (DOE) Malaysia, 1974.

[2] A.J.M.L. Borghans, W.M.A.van Gils, B. Huisman, and E. Wind. "10 years experience on the full scale anaerobic treatment of sugar industry wastewater in the Netherlands with the Biomethane process". In EWPCA Conference, Amsterdam, 15-19 September, 1986.

[3] J.J. Heijnen, A. Mulder, R. Wellevrede, J. Hols, and H.L.J.M. van Leeuwen. "Large scale anaerobic-aerobic treatment of complex industrial wastewater treatment of complex industrial wastewater using biofilm reactors". Wat. Sci. Tech. 23(7-8):1427-1436, 1991.

[4] G. Lettinga, A.F.M. van Velsen, W. de Zeeuw, and S.W. Hobma. "Feasibility of the upflow anaerobic sludge blanket (UASB) process". In Proceedings of International Conference on Environmental Engineering, New York: ASCE 35, 1979.

[5] P.J. Reynolds, E. Colleran. "Comparison of start up and operation of anaerobic fixed bed and hybrid sludge bed/fixed bed reactors treating whey waste water". In EWPCA Conference, 15-19 September, Amsterdam, 1988.

[6] M.A. Bull, R.M. Steritt and J.N. Lester. "An evaluation of four start-up regimes for anaerobic fluidized bed reactors". Biotech. Letters 5(5):333-338, 1983.

[7] A.N. Ma, S.C. Cheah and M.C. Chow. "Current status of palm oil processing wastes management". In Yeoh, B.G., Chee, K.S, Phang, S.M., Isa, Z., Idris, A. and Mohamed, M. (ed.) Waste management in Malaysia: Current status and prospects for bioremediation, Kuala Lumpur:111-136, 1993.

[8] K.H. Kam. "Scale-up studies on 2-stage biofilter POME treatment system." B.Sc. thesis, Universiti Pertanian Malaysia, Selangor, Malaysia, 1995. 
[9] M. Hafiz. "Combined anaerobic-aerobic treatment of industrial effluent utilizing fluidized bed technology”. B.Sc. thesis. Universiti Pertanian Malaysia, Selangor, Malaysia, 1996.

[10]T.K. Tiong,. "Performance evaluation of a high-rate anaerobic fluidized bed reactor using diluted palm oil mill effluent with a steady-state biofilm". B.Sc. thesis, Universiti Pertanian Malaysia, Selangor, Malaysia, 1994.

[11]J. Iza, E. Colleran, J.M. Paris and W.M. Wu. "International workshop on anaerobic treatment technology for municipal and industrial wastewaters: Summery paper". Wat. Sci. Tech. 24(8):1-16, 1991.

[12]Y. Hsu, and W.K Shieh. "Start-up of anaerobic fluidized bed reactors with acetic acid as the substrate". Biotech.Bioengg. 41:347-353, 1993.

[13]E. Oliva, J.C. Jacquart and C. Crevot. "Treatment of wastewater at the El Aguila brewery (Madrid, Spain)". Wat. Sci. Tech. 22(1-2):483-490, 1990.

[14]M. Denac and J.J. Dunn. "Packed and fluidized-bed biofilm reactor performance for anaerobic wastewater treatment". Biotech. Bioengg. 32:159-173, 1988.

[15]S.J. Chen, C.T. Li, and W.K. Shieh. "Performance evaluation of the anaerobic fluidized bed biofilm reactor: Methane production from glucose". In 40th Purdue University Industrial Waste Conference, West Lafayette.:925-936, 1985.

[16]G. Tchobanoglous and F.L. Burton. "Wastewater engineering: treatment, disposal and reuse". McGraw Hill Inc., 1991. 
